of Trouble," The Insider no. 10 (October 1992), 28.

5. Vladimir Kuzin, "Refugees in Central and Eastern Europe: Problem or Threat?" Report on Eastern Europe (January 18, 1991), 39.

6. Bohdan Nahaylo, "Ukraine and Moldova: The View from Kiev," RFE/RL Research $R e-$ port 1, no. 18 (May 1, 1992), 43; Oleg Shamsur, "Ukraine in the Context of New Eruropean Migrations," International Migration Review 97 (1992), 261.

7. Quoted in Elena Trifonova, " 200 Bessarabian Families Immigrate in a Year," Standard News (August 15, 1992).

8. See Cassandra Cavanaugh, "Conflict in Moldova: The Gagauz Factor," RFE/RL Research Report 1, no. 32 (August 14, 1992); Vladimir Socor, "Russian Forces in Moldova," RFE/RL Research Report 1, no. 34 (August 28, 1992).

9. AlexanderMilanov, "Challengeto OurNational Maturity," unpublished manuscript, December 1992.

10. Lazar Georgiev, "Brothers and Sisters, in Moldova Bulgarians Are Being Killed!" Duma (July 2, 1992), 7; Bohdan Nahaylo, "Ukraine and Moldova: The View from Kiev," RFE/RL Research Report 1, no. 18 (May 1, 1992), 43.

11. Duma (June 30, 1992), 2.

12. Nora Dimova, "For Several Days Now Bulgarians Are Mobilized in Moldova," Duma (July 3, 1992), 1.

13. 24 Hours (July 6, 1992), 6.

14. Mariana Boyadzhieva, "Bulgarians from the Former Soviet Union Seek Shelter in the Home Lands," Duma (September 71992$), 4$.

15. Mila Geshakova, "Bulgarians of Bessarabia Consider Us the Americans of the Balkans: Results of a BBSS International Gallup Poll with Minorities in the Former Socialist Countries," 24 Hours (July 6, 1992), 6.

16. Blagovest Nyagoulov, "Ethnic Revival or Assimilation? To Presumably Half a Million Bulgarians in the ex-USSR, Life is a Sea of Trouble," The Insider no. 10 (October 1992), 28.

17. Letter from Bulgaria no. 14 (September 7, 1992), 3.

18. Letter from Bulgaria no. 14 (September 1, 1992), 2.

19. Duma (November 20, 1992), 3.

20. Duma (November 10, 1992), 3.

21. Duma (November 21, 1992), 3.

22. Radka Petrova, "Bessarabian Bulgarians Seek Asylum in Our Country," Duma (July 21, 1992), 2.

23. Duma (August 13, 1992), 1; Letter from Bulgaria no. 13 (August 1992), 3.

24. Boyadzhieva, "Bulgarians from the Former Soviet Union," Duma (September 7, 1992).

25. Mitko Bozhkov, "Velko Valkanov Offers a Law Concerning the Bulgarians Abroad," Duma (October 6, 1992), 3.

\title{
A Sketch of the Migration and Refugee Situation in Russia
}

\author{
Irena Orlova
}

This article briefly analyses migratory processes in Russia in the 1990s and looks at the following problems:

- the impact of migration on the country's population size and composition causes, effects and composition of migration within the former U.S.S.R.

- the dynamics of emigration and the distribution of emigrants among major recipient countries

- special features of the 1992 emigration

- the impact of emigration on Russia's intellectual structure

Today's migratory processes reflect the general crisis that envelops the Russian polity, economy and culture. Streams of refugees and involuntary migrants are pouring into Russia from the republics of the former U.S.S.R. (the so-called "near abroad"), giving rise to new and unprecedented problems and changing the country's socio-demographic structure. Migration processes have begun to exert a substantial effect on the structure and size of the country's population.

For many years, natural increase was the main factor affecting population growth, although, since the mid-1970s, more people have been arriving in Russia than have been leaving it. Thus between the 1979 and 1989 censuses the Russian net migration equalled 180,000 people annually, but the contribution of net migration to population increase never exceeded 19 percent in a given year.

The picture has changed considerably in the last few years. This is due to a sharp decline in the birth rate and increased mortality. As a result, migration has become a much more important factor influencing population growth. In 1990-91, a third of the total population

Irena Orlova is a researcher at the Russian Academy of Science's Institute of Socio-Political Research in Moscow. increase was due to the net migration balance (see Table 1). In 1992, the inflow of refugees and involuntary migrants more than doubled. Even so, it could not outweigh losses due to lower birth rates and higher mortality rates. Thus in 1992, for the first time since World War II, there was an absolute decline in the size of the Russian population. Between 1991 and 1992 the Russian population shrank by 71,000 people (see Table 1 ).

Since the mid-1970s people have been arriving in Russia mainly from Central Asia, the Transcaucasus and Kazakhstan. In 1992, the migration wave from the Baltic countries increased by a factor of three. Among migrants, the proportion of refugees is constantly growing. On January 1, 1993 the Ministry of Internal Affairs registered 362,000 refugees1.6 times as many as in $1991 .^{1}$ Russians accounted for 44 percent of the total, Armenians for 18 percent, Meskhetian Turks for 8 percent, Ossetians for 7.9 percent and Azeris for 2.5 percent.

The main motives prompting this tidal wave of refugees and migrants are socio-economic, ethnic and political. ${ }^{2}$ Interethnic relations have become aggravated, nationalist organizations and parties have been galvanized, and discriminatory laws have been passed concerning citizenship and language in the former Soviet republics-all this in the context of rapidly deteriorating economic conditions and political instability. In early 1992, interethnic conflicts were cited as the main motive for going to Russia by 70 percent of migrants from Azerbaijan, 64 percent from Tajikistan, 63 percent from Georgia, 51 percent from Uzbekistan, 50 percent from Armenia, 47 percent from Latvia and 36 percent from Moldova.

In 1992, nearly two-thirds of the migrants from the near abroad who cited the aggravation of interethnic relations as their main motive for leaving were Russians. In addition, fully 78 percent of

Refuge, Vol. 13, No. 2 (May 1993) 
people who abandoned their permanent places of residence inside Russia due to interethnic conflicts were Russians. They left the territories of Chechen-Ingushetia, Dagestan, Tuva and North Ossetia.

It has been estimated that the flow of Russian-speaking people from the formerSovietrepublics and the non-Russian regions of the Russian Federation may result in the involuntary migration of anywhere from 400,000 to two million Russian-speaking people to Russia in the next four or five years. These figures represent roughly a third of the emigration potential of Russian-speaking people in the near abroad. ${ }^{3}$ Are Russians in Russia ready to receive their compatriots? The clear answer is no. Russia has neither the experience nor the legal basis for immigrant absorption, neither the economic resources nor the will. The machinery for receiving refugees has not yet been devised and official organizations are barely interested in solving the problem. The problem is particularly acute in the already-tense southern region of Russia (North Ossetia, Krasnodar territory, Stavropol territory and Rostov region), where nearly 70 percent of migrants were concentrated in 1992. In those areas, refugees and involuntary migrants compete with local populations in the markets for consumer goods, labour and housing, provoking new centres of ethnosocial tension, this time in the territory of Russia itself. ${ }^{4}$
It would nonetheless be incorrect to offer a simple negative evaluation of the consequences of forced migration. The growth of the ablebodied population could create favourable opportunities for improving the economic activity of regions suffering from labour shortages. Such positive consequences can, however, be realized only if practical steps are taken at all levels to organize the transportation, reception, housing and employment of migrants. To date, this has not happened to any significant degree. ${ }^{5}$ Such processes are developing spontaneously, bringing to naught all possible positive consequences of forced migration to Russia.

Let us turn now to emigration from Russia. Actual emigration rates are now high. The potential is still higher. Estimates of the potential emigration are characterized by a great range of opinion-from half a million to five million in the territory of the former U.S.S.R. in
Table 1

Changes in the Russian Population Due to Refugees and Involuntary Migrants, 1990-92 (in thousands)*

$199019911992^{* *}$

rrivals for permanent residence from:

the near abroad

$937.2 \quad 780.7 \quad 845.0$

$\begin{array}{lll}0.2 & 0.2 & 0.2\end{array}$

Departures for permanent residence to: the near abroad

$669.9 \quad 640.9 \quad 646.4$

Change in Russia's population $\quad 502.0 \quad 161.6 \quad 71.6$

The figures include arrivals and departures for work and study.

* Preliminary estimate

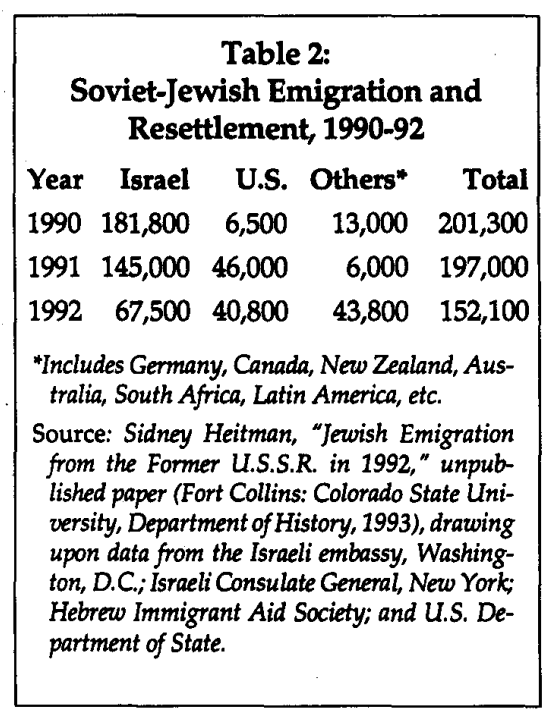

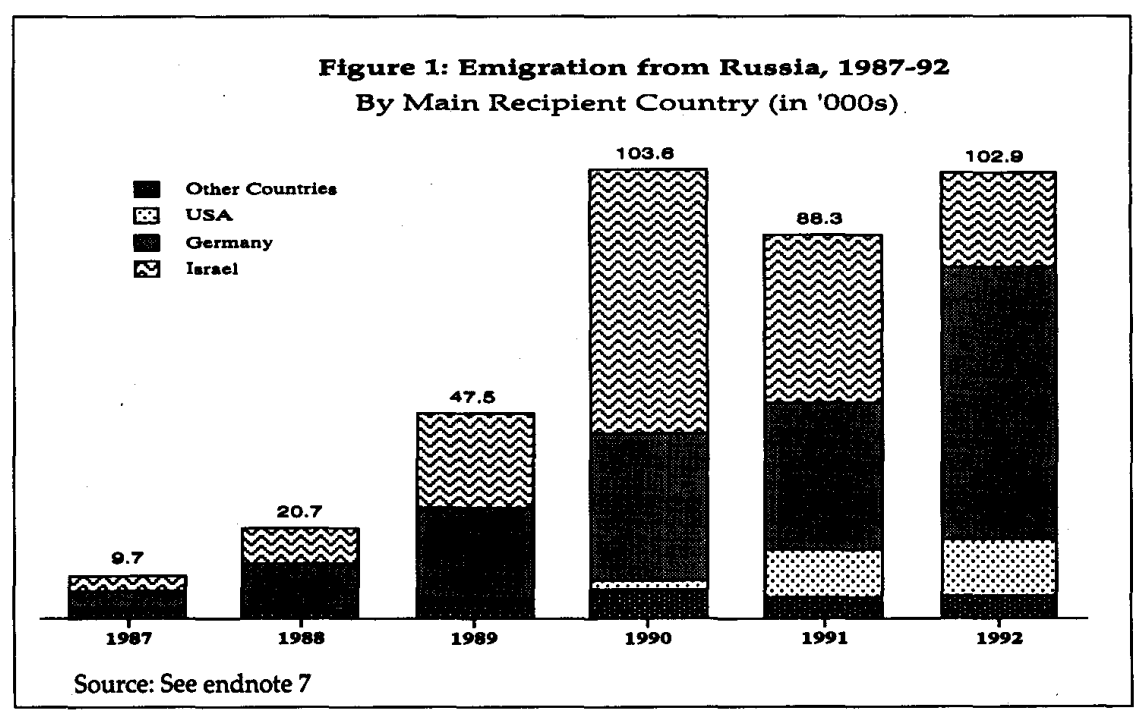


Russia, not theWest, will be receiving the overwhelmingbulk of migrants from the former Soviet republics. Survey data analysed by the Commission of the European Community and by a Canadian social scientist corroborate that conclusion. The latter estimated the emigration potential of Russia at 4.6 percent of the population, or 6.8 million people. ${ }^{6}$

Of course, there exists a very great difference between expressing the desire to emigrate in a survey and the realization of that desire. Actual emigration from Russia is estimated not in the millions but in the thousands. In 1992 it reached 102,900 people, exceeding the level of the previous year and nearly reaching the level of the peak year, 1990 (see Figure 1). I estimate that in the near future the level of emigration from Russia will vacillate around 100,000 .

\section{Emigration from Russia by Main Recipient States}

Current emigration from Russia is largely restricted to Germans and Jews. Indeed, so many people have emigrated from these two groups that they have been substantially eroded as important components of Russia's ethnic structure.

Comparing 1991 and 1992, we see that the number of Russian citizens departing for Germany has nearly doubled. That is because the whole complex of problems associated with ethnic Germans in Russia has not been solved and there is no solution in sight, while Germany has not established any quota for the entry of ethnic Germans. In addition, as we will see, there has been a recent upsurge in the number of Russian Jews going to Germany.

According to data from the Consular Service of the German Embassy in Moscow, nearly 20,000 Russian Germans are now applying for exit visas every month. To weaken this influx of emigrants, Germany insists on concluding an agreement with Russia concerning the "restoration of German statehood" in Russia, by which it means the creation of a German Autonomous Republic in the Volga Region. For the purpose of solving this problem the president of the Russian Federation issued a decree concerning the creation of a Russian-German settle- ment in the Volga Region. Local administrators have, however, blocked this process, using political instability and the results of a referendum carried out in the region as an excuse.

The second main feature of emigration in 1992 is a decline in the number of Jewish emigrants from 197,000 in 1991 to 152,100 in $1992 .^{8}$ (These and the following figures refer to Jewish emigration from the entire former U.S.S.R.) This decline is due largely to a sharp drop in the number of Jews leaving for Israel, which fell from 145,000 in 1991 to 67,500 in 1992. This decline was due mainly toincreased unemployment in Israel and the worsening of the conflict between Palestinians and Israeli Jews. There was also a modest decline in the number of Jews emigrating to the United States from 46,000 in 1991 to 40,800 in 1992. Interestingly, however, the number of Jews going to other countries increased sharply from 6,000 to 43,800 . That is largely because Germany began accepting more than 10,000 Rus-

\section{Table 3: Russian Emigrants, June 1-September 30, 1992, by Occupation, For Individuals over Fifteen Years of Age}

\begin{tabular}{|c|c|c|}
\hline & \multicolumn{2}{|c|}{ Number Percent } \\
\hline $\begin{array}{l}\text { Engineers and other } \\
\text { technical workers }\end{array}$ & 1,223 & 6.1 \\
\hline $\begin{array}{l}\text { Lecturers, teachers, } \\
\text { educators }\end{array}$ & $984^{*}$ & 4.9 \\
\hline Medical professionals & $750^{* *}$ & 3.7 \\
\hline $\begin{array}{l}\text { Students of institutes of } \\
\text { higher education and } \\
\text { technical schools }\end{array}$ & 576 & 2.9 \\
\hline $\begin{array}{l}\text { Economists, } \\
\text { accountants, clerks }\end{array}$ & 455 & 2.3 \\
\hline $\begin{array}{l}\text { Directors of enterprises } \\
\text { and cooperatives }\end{array}$ & 315 & 1.6 \\
\hline Researchers & 257 & 1.3 \\
\hline Subtotal: Skilled & 4,560 & 22.8 \\
\hline Workers & 6,137 & 30.7 \\
\hline Pensioners & 4,266 & 21.4 \\
\hline Unemployed & 2,509 & 12.6 \\
\hline Others & 1,700 & 8.5 \\
\hline No information & 797 & 4.0 \\
\hline Subtotal: All others & 15,409 & 77.2 \\
\hline Total & 19,969 & 100.0 \\
\hline $\begin{array}{l}\text { *Of these, } 65 \text { worked at } \\
\text { education. } \\
{ }^{*} \text { Of these, } 350 \text { had higher }\end{array}$ & $\begin{array}{l}\text { institutes of } \\
\text { education. }\end{array}$ & higher \\
\hline
\end{tabular}

sian-Jewish immigrants per year (see Table 2).

It is difficult to estimate the consequences of emigration for Russia's intellectual and scientific strength, sociodemographic structure and so forth. We may, however, draw some preliminary conclusions on the basis of available data. Some 54 percent of the emigrants who left Russia during the month of June 1992 had higher or technical secondary education. Meanwhile, amongmigrants within Russia and those coming from the near abroad, persons with such education constituted less than 40 percent of the total. ${ }^{9}$

These figures suggest that Russia is suffering a net loss of intellectual resources because skilled specialists cannot find work under present economic, political and ethnic conditions-or at least they are not satisfied that they can realize their creative potential. Table 3 , which gives a detailed occupational breakdown of Russian emigrants for the period June 1-September 30, 1992, the only period for which such data are so far available, adds weight to this view.

At present, the emigration of highly trained specialists is constrained to a certain degree by the growing opportunities for forming enterprises in Russia. A significant number of highly trained specialists are becoming entrepreneurs. However, Western countries are very interested in Russia's intellectual resources. They may be inclined to formulate immigration criteria that will increase the size of the Russian brain drain and, as an unintended consequence, increase illegal immigration of nonspecialists, especially to Europe. ${ }^{10}$ a

\section{Notes}

1. Unless otherwise noted, data are from Information Bulletin N17-1-16/11 (Moscow: State Statistics Board of the Russian Federation, January 14, 1993).

2. This is according to research conducted by the State Statistics Board of the Russian Federation and the Ministry of Internal Affairs in Russia's twenty-three territories. Ninety-two thousand respondents aged sixteen and over who arrived in populated areas of these territories were questioned.

3. This is according to the Long-Term "Migration" Programme of the Russian Federation (Moscow: May 18, 1992), 6. 